\title{
TIPE-TIPE KESALAHAN SISWA DALAM MENYELESAIKAN SOAL MATEMATIKA PADA ATURAN EKSPONEN DAN SCAFFOLDINGNYA: STUDI KASUS DI SMKN 11 MALANG
}

\author{
Ristina Wahyuni \\ Didik Nurhadi
}

\begin{abstract}
Abstrak: Tujuan penelitian adalah untuk menganalisis kesalahan yang dilakukan siswa dalam menerapkan aturan eksponen dan mendeskripsikan bentuk scaffolding untuk mengatasinya. Metode penelitian yang digunakan adalah deskriptif dengan pendekatan kualitatif. Tes dan wawancara digunakan untuk mengumpulkan data dari kelas X KPR 1 SMKN 11 Malang. Selanjutnya, tahapan analisis datanya adalah membuat catatan jawaban, mengidentifikasi faktor-faktor yang menjadi pemikiran, mengelompokkan kesulitan siswa, dan menarik kesimpulan. Hasil penelitian menunjukkan bahwa tipe-tipe kesalahan siswa pada penerapan aturan eksponen adalah basic error, missing information, dan partial insight. Sementara itu, bentuk scaffolding yang diberikan kepada siswa adalah enviromental provisions, reviewing dan restructuring, serta developing contextual thinking. Kesimpulannya adalah bahwa proses pembelajaran sangat penting untuk keberhasilan belajar siswa.
\end{abstract}

Kata-kata Kunci: tipe kesalahan siswa, scaffolding, aturan ekponen

\begin{abstract}
Types of Students' Errors on Completing Math Problems in the Exponent Rules and its Scaffolding: Case Study in SMKN 11 Malang. This research aims to analyze errors made by students on applying exponent rules and to describe the form of scaffolding to overcome these errors. The method was a descriptive method with a qualitative approach. Furthermore, a test and an interview were used to collect data from students at class X Nurse 1 in SMKN 11 Malang. Data were analyzed by taking notes of answers, identifying factors that become thoughts, classifying student difficulties, and drawing conclusions. The results showed that the types of student errors on applying exponent rules were basic errors, missing information, and partial insight. Meanwhile, the forms of scaffolding given to students were environmental provisions, reviewing and restructuring, and developing contextual thinking. The research concluded that the learning process was very important for student learning success.
\end{abstract}

Keywords: type of student error, scaffolding, exponent rules

$\mathrm{U}$ ntuk mempelajari suatu pengetahuan baru, hirarki belajar sangat diperlukan dalam pembelajaran. Hirarki ini diperlukan dalam berpikir matematik. Hirarki merupakan Dengan kata lain, pengetahuan prasyarat harus dimiliki siswa dalam menyelesaikan kegiatan pembelajaran menentukan tercapai atau tidaknya tujuan pembelajaran yang dilakukan. Berdasar pengalaman peneliti selama

Ristina Wahyuni adalah Guru SMK Negeri 11 Malang. Alamat: Jl. Pelabuhan Bakahuni No.1, Bakalankrajan, Sukun, Kota Malang, 65148. Email: aristina@smkn11malang.sch.id. Didik Nurhadi adalah Dosen Jurusan Teknik Mesin Universitas Negeri Malang. Alamat Kampus: Jl. Semarang No. 5 Malang 65145 
mengajar di SMKN 11 Malang, banyak siswa yang kurang memahami dan masih merasa kesulitan dalam menyelesaikan tugasnya disebabkan kurang memahaminya materi prasyarat yang seharusnya sudah diketahui dan dipahami oleh siswa sebelum mereka menyelesaikan suatu materi yang dipelajari. Hal ini terlihat dari hasil pekerjaan siswa yang masih salah dan belum memahami pengetahuan prasyarat tersebut.

Selanjutnya, pada pembelajaran matematika, materi eksponen sebenarnya telah diajarkan guru kepada siswa di SMP. Namun ini masih banyak siswa yang masih kesulitan. Kesulitan siswa dalam mempelajarinya terlihat dari banyakya siswa yang melakukan kesalahan dalam menyelesaikan soal-soal ketika materi eksponen merupakan materi prasyarat dalam menyelesaikan konsep yang sedang dipelajari. Hal ini juga didukung dengan adanya keluhan dari guru mata pelajaran fisika atau kimia yang menyampaikan banyaknya siswa yang belum memahami aturan eksponen ketika mata pelajaran tersebut mempelajari suatu materi dengan konsep eksponen sebagai prasyaratnya. Berdasarkan hasil pekerjaan siswa, pada saat guru mengajarkan materi eksponen ditemukan berbagai kesalahan siswa dalam menyelesaikannya.

Kesalahan dalam menerapkan eksponen dikarenakan kesalahan prosedur dan tidak adanya makna dalam pemahaman konsep (Blanco dan Garrote, 2007) dan tidak adanya kontinuitas konsep (Prediger, 2011). Sehingga upaya peningkatan penalaran matematika perlu dilakukan dalam pembelajaran matematika. Tujuannya agar siswa mampu menggunakan konsep-konsep matematika yang telah dipelajari sebelumnya untuk menyelesaikan permasalahan matematika.

Guru tidak hanya mentransfer pengetahuan yang telah dimilikinya, melainkan juga membantu siswa memben- tuk pengetahuannya sendiri. Legutko (2008) menyatakan bahwa guru tidak perlu takut ketika siswanya membuat kesalahan. Kesalahan siswa tersebut dapat dianalisis dengan komunikasi secara intensif dengan siswa sehingga pemahaman siswa tentang konsep akan menjadi benar.

Kajian tentang analisis kesalahan siswa telah dilakukan oleh beberapa peneliti (Brodie, 2010; Trisulawati, 2009; Savvi, 2014; dan Yuli, 2015). Berdasar penelitian yang telah dilakukan tersebut, hasil penelitian menyimpulkan diperlukan pengkajian mendalam tentang polapola kesalahan yang dilakukan siswa, apa penyebabnya serta bagaimana penanggulangannya. Hal ini dapat dilakukan dengan menganalisis terlebih dahulu kesalahan-kesalahan yang dilakukan siswa. Setelah itu diperlukan upaya pemberian bantuan seminimal mungkin atau yang lebih dikenal dengan scaffolding. Scaffolding merupakan gagasan yang menggambarkan bantuan orang yang mampu (guru) kepada siswa dan secara perlahan-lahan bantuan tersebut akan ditinggalkan ketika siswa telah dapat menyelesaikan permasalahan sendiri (Anghileri, 2006). Berdasarkan penjelasan diatas, tujuan penelitian ini dilakukan untuk memahami kesalahan yang dilakukan siswa dalam menerapkan aturan eksponen dan mendeskripsikan scaffolding yang dapat membantu siswa dalam menerapkan aturan eksponen.

\section{METODE}

Metode penelitian ini adalah deskriptif dengan pendekatan penelitian. Subjek penelitian ini adalah 4 siswa yang dipilih dari 32 siswa kelas X - KPR1. Emilian ini dilakukan setelah mereka mengerjakan soal tes diagnostic dan dilakukan pengoreksian terhadap hasil jawaban siswa. Akhirnya dipilihlah satu orang yang kemampuan matematika baik (Par- 
sitipan 1), satu orang yang kemampuan matematika sedang (Partisipan 2) dan dua orang yang berkemampuan matematika rendah (Partisipan 3 dan Partisipan 4).

Selanjutnya, teknik pengumpulan data yang digunakan adalahtes dan wawancara. Tes dilakukan sebanyak dua kali: Tes diagnostic dan tes akhir. Tes diagnostik diberikan untuk mendiagnosa kesalahan yang dilakukan siswa dalam menyelesaikan soal eksponen. Sedangkan, tes akhir diberikan setelah pemberian scaffolding untuk mengetahui keefektifan scaffolding yang dilakukan. Wawancara digunakan untuk mendalami dan mengklarifikasi penyebab kesalahan yang dilakukan siswa. Soal tes terdiri dari 2 soal dalam bentuk soal uraian dan telah divalidasi oleh seorang dosen Universitas Negeri Malang, seorang Guru SMK Negeri 4 Malang, dan seorang guru SMK Negeri 11 Malang. Setelah diberikan tes diagnostic dan dilakukan pengoreksian terhadap jawaban siswa, peneliti kemudian melakukan wawancara kepada empat subjek penelitian yang dipilih. Setelah mengetahui penyebab kesalahan dan kesulitan yang dilakukan siswa, selanjutnya guru memberikan scaffolding untuk mengatasi kesulitan yang dialami siswa. Soal tes diagnostic dapat dilihat pada Tabel 1.

Selanjutnya, tahapan yang dilakukan untuk menganalisis data penelitian ini adalah (1) membuat catatan jawaban pada langkah-langkah yang benar, (2)

Tabel 1. Soal Tes Diagnostik

\begin{tabular}{|c|c|}
\hline No & Soal \\
\hline 1. & $\begin{array}{l}\text { Sederhanakan dan ubahlah } \\
\text { persamaan ini dalam pangkat } \\
\text { positif. } \\
\frac{\left(4 x^{2} y^{3}\right)^{5}}{\left(2 x^{-3}\right)^{10}}\end{array}$ \\
\hline 2. & $\begin{array}{l}\text { Tentukan nilai } x \text { yang memenuhi } \\
\text { persamaan ini. } \\
\frac{16^{-2 x+4}}{2^{x+1}}=8^{3}\end{array}$ \\
\hline
\end{tabular}

membuat catatan jawaban masing-masing subjek pada langkah-langkah yang salah, (3) mengidentifikasi faktor-faktor yang menjadi pemikiran dibalik jawaban siswa (penyebab kesalahan), (4) mengelompokkan kesulitan siswa berdasarkan empat kesalahan yang berdasarkan teori yang dikembangkan oleh Brodie (2010), dan (5) menarik kesimpulan. Tipe tersebut adalah basic error, missing information, dan partial insight. Tipe kesalahan bassic error adalah kesalahan konsep dasar dan kesalahan memahami soal. Tipe kesalahan appropriate error adalah sebagian dari konsep yang tidak dipahami namun sudah memahami konsep dasar. Tipe kesalahan missing information adalah tidak dapat menjawab secara lengkap atau tidak dapat memproses lebih lanjut solusi dari permasalahan. Sementara, tipe kesalahan partial insight adalah sedikit kesalahan yang disebabkan karena kesalahan perhitungan atau karena kecerobohan.

Sedangkan untuk mengatasi kesulitan siswa, penulis memberikan tiga level scaffolding sesuai dengan teori yang dinyatakan oleh Anghileri (2006). Level pertama adalah environmental provisions. Ini adalah bantuan yang diberikan dengan mempersiapkan lingkungan belajar atau memberikan tugas terstruktur. Level kedua adalah explaining, reviewing, dan restructuring. Level ini adalah bantuan yang diberikan guru untuk menjelaskan, mengulas kembali atau merestrukturisasi konsep yang diperoleh siswa. Sementara, level ketiga adalah developing conceptual thinking. Level ini adalah bantuan yang diberikan dengan melibatkan siswa dengan mengembangkan konsep yang siswa miliki.

\section{HASIL}

Pada bagian ini dikelompokkan menjadi dua: Kesalahan dan penyebabnya siswa dalam menyelesaikan soal pe- 


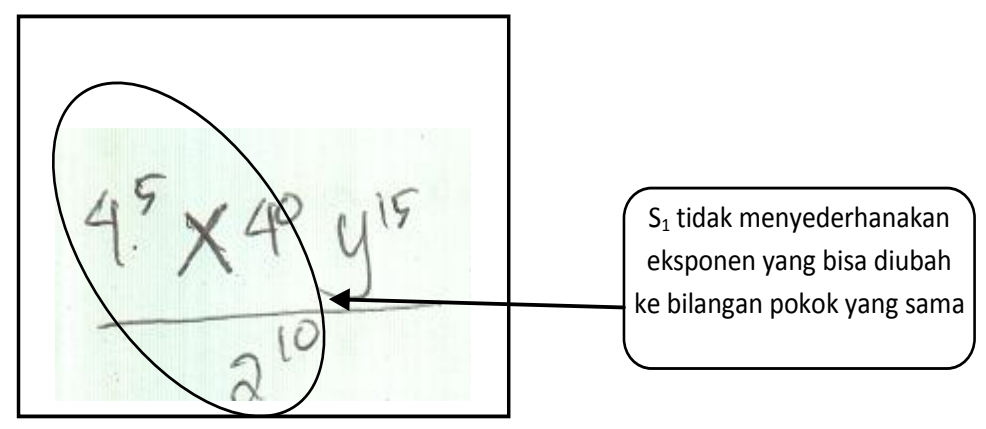

Gambar 1. Kesalahan $S_{1}$ dalam Menyederhanakan Eksponen

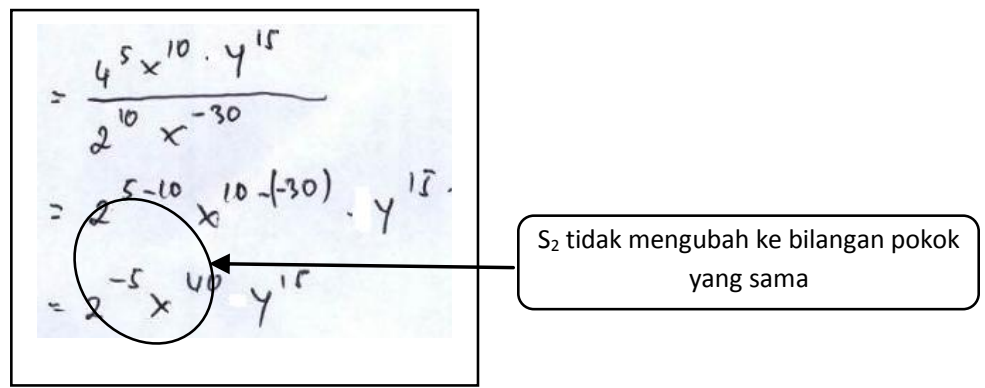

Gambar 2. Kesalahan $S_{2}$ dalam Menyederhanakan Eksponen

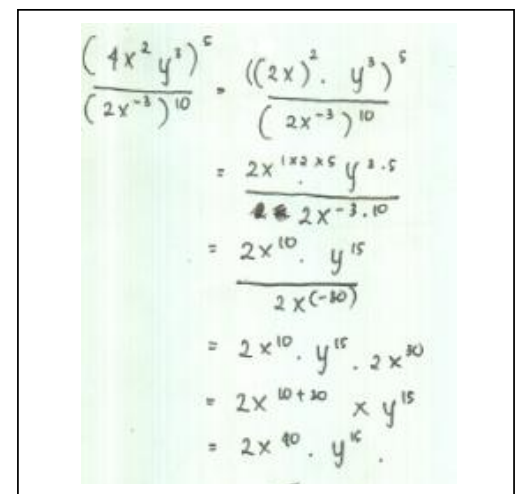

Gambar 3. Kesalahan $S_{3}$ dalam Menyederhanakan Eksponen

$$
\begin{aligned}
\frac{\left(4 x^{2} y^{3}\right)^{5}}{\left(2 x^{-3}\right)^{10}}=\frac{20 x^{10} y^{15}}{20 x^{-30}} & =20 x^{10} \cdot y^{15} \cdot 20 x^{30} \\
& =400 x^{40} \cdot y^{15}
\end{aligned}
$$

Gambar 4. Kesalahan $S_{4}$ dalam Menyederhanakan Eksponen

nyederhanaan eksponen dan proses scaffolding untuk mengatasinya. Selanjutnya, hasilnya adalah sebagai berikut.

Kesalahan dan penyebabnya siswa dalam menyelesaikan soal menyederhanakan eksponen pada soal tes diagnostic 1 adalah seperti pada Gambar 1 sampai Gambar 5.

\section{PEMBAHASAN}

Selanjutnya, bagian ini terpagi menjadi dua: Kesalahan dan penyebabnya siswa dalam menyelesaikan soal penyederhanaan eksponen dan proses scaffoldding untuk mengatasinya. Selanjutnya, uraiannya adalah sebagai berikut. 


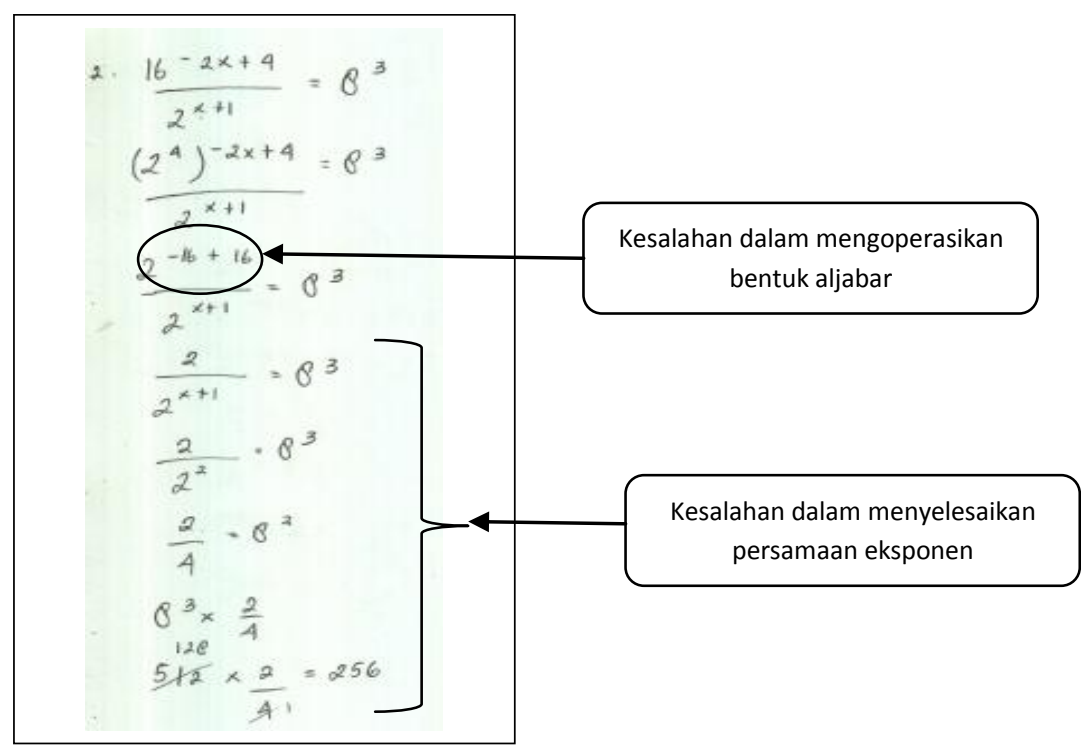

Gambar 5. Kesalahan $\mathbf{S}_{\mathbf{4}}$ dalam Menyederhanakan Eksponen

Kesalahan dan Penyebabnya Siswa dalam menyelesaikan soal menyederhanakan eksponen

Soal tes diagnostic 1. Dalam menyelesaikan soal tentang menyederhanakan eksponen, Subyek $1\left(\mathrm{~S}_{1)}\right.$ tidak mengalami kesulitan. $\mathrm{S}_{1}$ dapat menyederhanakan pangkat dari masing-masing pembilang dan penyebut juga memahami aturan $(a . b)^{m}$ dengan baik. $\mathrm{S}_{1}$ juga memahami aturan dalam mengubah pangkat negative menjadi positif, yaitu $\frac{1}{a^{-m}}=a^{m}, a \neq 0$. Namun $S_{1}$ tidak dapat memproses lebih lanjut solusi dari permasalahan, yaitu tidak menyederhanakan eksponen $\frac{4^{5}}{2^{10}}$. Berdasarkan jenis kesalahan yang dikembangkan Brodie, tipe kesalahan $S_{1}$ merupakan kesalahan tipe (3) missing information. Hal ini disebabkan pembelajaran yang dilakukan siswa kurang bermakna. Sesuai dengan penelitian yang dilakukan Blanco and Garrote (2007) menyebutkan bahwa tidak adanya makna adalah penyebab dari kegagalan untuk memahami konsep dan proses aljabar. Lebih jelasnya kesalahan yang dilakukan $S_{1}$ dapat dilihat pada Gambar 1.

Sedangkan Subyek $2\left(\mathrm{~S}_{2}\right)$ dalam menyederhanakan eksponen, sudah memahami aturan dasar dan sifat- sifat eksponen. $S_{2}$ mampu memahami aturan $\frac{a^{m}}{a^{n}}, a \neq 0$. Namun pada langkah penyelesaiannya $\mathrm{S}_{2}$ menyederhanakan eksponen tanpa mengubah bilangan pokok ke bilangan pokok yang sama, yaitu menyederhanakan $\frac{4^{5} x^{10} y^{15}}{2^{10} x^{-30}}$ menjadi $\frac{2^{5-10} \cdot x^{10} y^{15}}{x^{-30}}$. Dari hasil wawancara, $\mathrm{S}_{2}$ menyampaikan ia kurang teliti dalam mengerjakan soal tersebut. Sebenarnya $S_{2}$ memahami bagaimana menyederhanakan $\frac{4^{5} x^{10} y^{15}}{2^{10} x^{-30}}$ dengan mengubah ke bilangan pokok yang sama terlebih dahulu. Setelah $S_{2}$ mengetahui kesalahan yang dilakukan, $S_{2}$ selanjutnya menyelesaikan kembali soal menyederhanakan eksponen tersebut. Tipe kesalahan yang dilakukan $S_{2}$ merupakan kesalahan tipe partial insight. $\mathrm{S}_{2}$ sudah memahami aturan eksponen, namun $\mathrm{S}_{2}$ melakukan kecerobohan dalam menyederhanakan eksponen. Ketidaktelitian siswa dalam menghitung hasil operasi seringkali disebabkan siswa tidak melakukan kroscek ulang jawaban terhadap soal maupun gambar yang tertera pada soal. Sesuai dengan hasil penelitian Ureyen (2006) yang menyatakan bahwa "If the students had followed this checking procedure, they could have found some clues to help them find the correct solution set". Kesalahan $\mathrm{S}_{2}$ dalam 
menyederhanakan eksponen dapat dilihat pada Gambar 2.

Subyek $3\left(\mathrm{~S}_{3}\right)$ dalam menyelesaikan soal menyederhanakan eksponen melakukan kesalahan tipe basic error. $\mathrm{S}_{3}$ tidak memahami aturan dasar eksponen. $\mathrm{S}_{3}$ tidak memahami aturan $(a . b)^{m}$ dengan baik dan melakukan kesalahan dalam menyederhanakan bentuk $\frac{a^{m}}{a^{n}}$. S 3 juga tidak memahami aturan $\frac{1}{a^{-m}}=a^{m}, a \neq 0$ dan $a^{m} \cdot a^{n}=a^{m+n}$. Dari hasil wawancara yang peneliti lakukan $S_{3}$ menyampaikan tidak memahami aturan dasar eksponen. Hal ini dibuktikan pada saat wawancara konsep dasar aturan eksponen tidak dimengerti oleh $\mathrm{S}_{3}$. Agar siswa tidak mengulang kesalahan yang sama maka peneliti meminta siswa untuk meneliti kembali jawaban yang dilakukan, saat itu siswa menyadari ketidaktelitiannya sekaligus mengetahui penyebab kesalahan tersebut. Hal ini didukung pendapat Willis (2010:47) bahwa, "Eliminating mathematical misconceptions is difficult, and merely repeating a lesson or providing extra time for practice will not help. A better approach is to show students common errors and help them examine completed sample problems that demonstrate these common errors. This method also gives you an opportunity to reinforce critical foundational skills". Kesalahan yang dilakukan $\mathrm{S}_{3}$ dalam menyederhanakan eksponen dapat dilihat pada Gambar 3.

Penyelesaian soal tentang menyederhanakan eksponen, $\mathrm{S}_{4}$ tidak memahami aturan eksponen $(a \cdot b)^{m} \cdot \mathrm{S}_{4}$ mengubah $\left(4 x^{2} y^{3}\right)^{5}$ menjadi $20 x^{10} y^{15}$ serta mengubah $\left(2 x^{-3}\right)^{10}$ menjadi $20 x^{-30}$. Kesalahan yang dilakukan $\mathrm{S}_{4}$ ini mirip dengan temuan penelitian yang dilakukan oleh Lim (2010) yaitu siswa hanya mengalikan suku yang ada variabelnya saja tanpa mengalikan kosntanta. Hal ini disebabkan kurangnya pemahaman dalam menerapkan aturan distributif per- kalian terhadap penjumlahan. Untuk langkah berikutnya $\mathrm{S}_{4}$ melakukan kesalahan dalam menyederhanakan bentuk $\frac{a^{m}}{a^{n}}, a \neq 0$. Ia mengubah bentuk $\frac{1}{20 x^{-30}}$ menjadi $20 x^{30}$. Selanjutnya $\mathrm{S}_{4}$ melakukan kesalahan kembali dalam menyederhanakan eksponen. Secara keseluruhan dapat disimpulkan bahwa $\mathrm{S}_{4}$ tidak memahami aturan eksponen. Berdasar tipe kesalahan yang dikembangkan Brodie, ini dapat disimpulkan bahwa $\mathrm{S}_{4}$ melakukan kesalahan tipe basic error. Hal ini dikarenakan proses pembelajaran sebelumnya kurang bermakna sehingga siswa melakukan kesalahan konsep. Hal ini didukung pendapat Blanco and Garrote (2007) yang menyatakan bahwa tidak adanya makna adalah penyebab dari kegagalan untuk memahami konsep dan proses aljabar. Lebih jelasnya kesalahan $\mathrm{S}_{4}$ dalam menyederhanakan eksponen dapat dilihat pada Gambar 4 .

Soal tes diagnostic nomor $2 . \mathrm{S}_{1}$ dalam menyelesaikan soal nomor 2 tentang persamaan eksponen sudah mengubah 16 menjadi bentuk eksponen dengan bilangan pokok 2. Namun pada langkah selanjutnya $S_{1}$ melakukan kesalahan dalam menyederhanakan eksponen. $\mathrm{S}_{1}$ mengubah $\frac{2^{4(-2 x+4)}}{2^{x+1}} \quad$ menjadi $2^{(4-1)(-2 x+4)-(x+1)}$. Dari hasil wawancara terlihat $S_{1}$ tidak memahami bentuk eksponen yang memuat variabel. Untuk langkah selanjutnya $S_{1}$ tidak memahami bagaimana menyelesaikan persamaan eksponen. Dalam wawancara yang dilakukan peneliti, $S_{1}$ dalam menyelesaikan persamaan eksponen menganggapnya seperti perkalian. Langkah $S_{1}$ menyelesaikan $2^{(4-1)(-2 x+4)-(x+1)}=8^{3}$ mengubahnya $\operatorname{ke}(2 x+4)-(x+1)=\frac{8^{3}}{2^{3}}$. Berdasar tipe kesalahan yang dilakukan $S_{1}$, kesalahan dalam menyelesaikan soal persamaan eksponen tersebut termasuk tipe basic error. 
Dalam menyelesaikan soal nomor 2 persamaan eksponen, $S_{2}$ terlihat tidak memahami aturan eksponen $a^{-m}=\frac{1}{a^{m}}$ dengan baik. $S_{2}$ mengubah $16^{-2 x+4}=$ $\frac{1}{16^{2 x+4}}$. Pada langkah berikutnya, $S_{2}$ tidak memahami bagaimana menyelesaikan persamaan eksponen. $\mathrm{S}_{2}$ mengalikan bilangan pokok utuk kemudian menyelesaikan eksponen tersebut. Namun, $S_{2}$ tidak menyamakan bilangan pokok terlebih dahulu. $S_{2}$ menyelesaikan $\frac{1}{16^{2 x+4}} \times \frac{1}{2^{x+1}}=$ $8^{3}$ menjadi $\frac{1}{32^{2 x+x+4+1}}=8^{3}$. Untuk langkah berikutnya, $\mathrm{S}_{2}$ dalam menyelesaikan persamaan $32^{-3 x+5}=8^{3}$. $S_{2}$ menyelesaikannya menjadi $3 x+5=3$ tanpa mengubah eksponen ke bilangan pokok yang sama. Kesalahan yang dilakukan $S_{2}$ dalam menyelesaikan persamaan eksponen tersebut termasuk kesalahan tipe basic error.

$\mathrm{S}_{3}$ dalam menyelesaikan persamaan eksponen melakukan kesalahan dalam mengoperasikan bentuk aljabar. $\mathrm{S}_{3}$ menghitung hasil dari $-8 x+16=-8 x$. Hal ini disebabkan karena siswa tidak memahami operasi bentuk aljabar dan kurangnya pemahaman dalam konsep operasi bilangan bulat. Kesalahan yang dilakukan siswa tersebut, didukung temuan penelitian yang dilakukan oleh Yakin (2011) yang menyebutkan bahwa kesalahan siswa saat menyederhanakan bentuk aljabar disebabkan ketidakpahaman mereka terhadap prosedur menyederhanakan aljabar maupun pemfaktoran.

Dalam menyelesaikan soal tersebut juga terlihat $S_{3}$ tidak memahami aturan $\frac{a^{m}}{a^{n}}, a \neq 0$. Dari hasil perhitungan yang ia lakukan, $\mathrm{S}_{3}$ mengubah $\frac{2^{-8 x}}{2^{x+1}}$ menjadi $2^{-8 x} \cdot 2^{-x+1}$. Dan selanjutnya $S_{3}$ tidak dapat menyelesaikan persamaan eksponen. Tipe kesalahan yang dilakukan $\mathrm{S}_{3}$ dalam menyelesaikan persamaan eksponen merupakan tipe kesalahan basic error.
Dalam menyelesaikan soal persamaan eksponen, $\mathrm{S}_{4}$ melakukan kesalahan tipe basic error. $\mathrm{S}_{4}$ melakukan kesalahan dalam mengoperasikan dan menggunakan sifat distributive pada operasi bentuk aljabar. $\mathrm{S}_{4}$ menyelesaikan $\left(2^{4}\right)^{-2 x+4}$ menjadi $2^{-16+16} . S_{4}$ juga tidak memahami bagaimana menyelesaikan persamaan eksponen. Lebih jelasnya kesalahan $\mathrm{S}_{4}$ dalam menyelesaikan persamaan eksponen, dapat dilihat pada Gambar 5.

Keempat subjek penelitian tidak memahami bagaimana cara menyelesaikan persamaan eksponen. Dalam menentukan nilai $x$, keempat subjek tidak dapat menentukan nilai $x$ yang ditanyakan. Hal ini disebabkan siswa tidak memahami arti persamaan. Hal ini didukung pendapat Al-Jupri (2014) yang menjelaskan bahwa siswa tidak memahami bahwa persamaan merupakan sebuah proses perhitungan.

Selain tidak memahami bagaimana mencari selesaian dari persamaan eksponen, $S_{3}$ dan $S_{4}$ juga mengalami kesulitan dalam mengoperasikan bentuk aljabar. Hal ini disebabkan siswa belum begitu memahami materi prasyarat yang harus dikuasai siswa dalam menyelesaikan persamaan eksponen. Sebelum memulai pembelajaran tentang materi baru hendaknya guru perlu mengetahui sejauh mana pemahaman siswa terhadap pengetahuan prasyarat yang dimiliki siswa. Hal ini dimaksudkan untuk menghindari kesalahan pemahaman terhadap konsep materi baru yang mengakibatkan lemahnya penguasaan materi terhadap materi matematika yang akan dipelajari di tingkat selanjutnya. Sesuai dengan pendapat Legutko (2008) bahwa "when introducing new concepts or procedures, knowledge about errors informs teachers what to focus on, what to clarify, how to negotiate the comprehension of new terms in order to avoid a certain type of errors, and how to positively use the occurring errors". 
Dengan mengetahui ketidakpahaman siswa terhadap materi penunjang keterampilan menyelesaikan soal persamaan eksponen maka guru dapat memberikan bimbingan yang tepat untuk membantu siswa mengatasi kekurangannya tersebut. Cowan (2006) menyatakan bahwa bimbingan yang diberikan guru untuk mengatasi kesalahan konsep materi terdahulu adalah dengan mengulang kembali materi sebelumnya dengan penyampaian yang lebih rinci dan bermakna sehingga siswa mendapat pemahaman yang lebih baik dari sebelumnya. Menurut Kurniasih (2012), guru memberikan bantuan belajar secara penuh dan kontinu, dalam hal ini scaffolding untuk membantu siswa membangun pemahaman atas pengetahuan dan proses yang baru.

Kesalahan yang dilakukan siswa dalam menyelesaikan soal menyederhanakan eksponen dan persamaan eksponen banyak yang disebabkan adanya pengaruh materi terdahulu. Materi yang baru dipelajari akan masuk ke dalam skema berfikir yang baru. Pada saat materi terdahulu tidak benar-benar dikuasai dan dipahami oleh peserta didik, akibatnya skema berfikir akan jadi masalah. Hal ini sesuai dengn teori konstruktivisme yang disampaikan oleh Walle (2010) yang menyatakan bahwa "existing schemas are often referred to as prior knowledge".

Proses Scaffolding untuk Mengatasinya Pada menyederhanakan eksponen, scaffolding yang diberikan pada penelitian ini mengacu pada tiga level scaffolding yang dikemukakan Anghileri (2006), yaitu level 1 : environmental provisions; level 2: explaining, reviewing (meliputi: looking, touching, and verbalizing; prompting and probing question; interpreting students action dan parallel modelling); dan restructuring (meliputi identifying meaningfull context dan simplifying the problem); level 3: developing conceptual thinking. Pemberian scaffolding disesuaikan dengan kesulitan dan ke- salahan yang dilakukan siswa. Pelaksanaannya dilakukan secara individu. Hal ini dilakukan untuk memaksimalkan kemampuan yang dimiliki siswa. Sesuai dengan pendapat Stuyf (2002) yang menyampaikan "scaffold instruction is individualized so it can benefit each learner. One of the primary benefits of scaffolding instruction is that it engages the learner. The learner does not passively listen to information presented instead through teacher prompting the learner builds on prior knowledge and forms new knowledge".

$\mathrm{S}_{1}$ dalam menyederhanakan eksponen mengalami kesulitan dalam menyederhanakannya ketika bilangan pokoknya tidak sama. Untuk membantu menyelesaikan kesulitan subjek tersebut, peneliti memberikan satu kali scaffolding dengan mengingatkan kembali tentang mengubah bentuk eksponen menjadi bentuk eksponen dengan bilangan pokok yang sama. Dari pemberian scaffolding tersebut, $S_{1}$ dapat melanjutkan menyelesaikan soal tersebut. Pemberian scaffolding yang diberikan ini sesuai dengan jenis scaffolding Anghileri level 2 yaitu reviewing: parallel modelling.

Dalam menyelesaikan soal nomor $2, \mathrm{~S}_{2}$ menyederhanakan eksponen tanpa mengubah ke bilangan pokok yang sama. $\mathrm{S}_{2}$ menyederhanakan $\frac{4^{5} x^{10} y^{15}}{2^{10} x^{-30}}$ menjadi $\frac{2^{5-10} \cdot x^{10} y^{15}}{x^{-30}}$. Dalam wawancara yang dilakukan peneliti, $S_{2}$ menyampaikan kurang teliti dalam menyelesaikan soal. Berikut transkrip wawancara antara peneliti $(P)$ dengan subjek $2\left(\mathrm{~S}_{2}\right)$ :

$\mathrm{P}$ : Mengapa ini $2^{5}$ ? Dari mana $2^{5}$ ?

$\mathrm{S}_{2}$ : Dari pembilang bu.

$\mathrm{P}$ : Maksudmu $4^{5} \mathrm{x}^{10} \mathrm{y}^{15}$ ini? (sambil menunjuk jawaban siswa)

$S_{2}$ : Ya bu...(kemudian siswa mengernyitkan dahi) Lho... kok $2^{5}$ ? seharusnyakan $4^{5}$. Salah jawaban saya bu 
$\mathrm{P} \quad$ : Kenapa menuliskan $2^{5}$ ?

$\mathrm{S}_{2}:$ Salah saya bu. Kurang teliti

$\mathrm{P}$ : Sekarang coba diganti bukan $2^{5}$. Bagaimana penyelesaiannya? bisa?

$\mathrm{S}_{2}$ : Bisa bu...

(siswa menjawab kembali soal tentang menyederhanakan eksponen)

Melalui wawancara tersebut, peneliti memberikan scaffolding dengan meminta $\mathrm{S}_{2}$ untuk melihat dan meneliti kembali hasil pekerjaannya. Pemberian scaffolding yang diberikan tersebut sesuai dengan jenis scaffolding Anghileri level 2 reviewing: looking, touching and verbalizing.

$\mathrm{S}_{3}$ dalam menyederhanakan eksponen, tidak memahami aturan dasar eksponen $(a . b)^{m}$. Ia menganggap $(a . b)^{m}=$ $a b^{m}$. Langkah awal pemberian scaffolding yang dilakukan oleh peneliti untuk menanamkan konsep $(a . b)^{m} \neq a b^{m}$. Peneliti memberikan 2 bentuk perkalian berulang berbeda, yaitu perkalian $2 x \times 2 x$ $\times 2 x \times 2 x \times 2 x$ dan $2 x \times x \times x \times x \times x$ untuk memberikan pemahaman bahwa $(2 x)^{5} \neq 2 x^{5}$. Pemberian Scaffolding yang diberikan pada $S_{3}$ ini sesuai dengan jenis Scaffolding Anghileri level $2 \mathrm{re}$ structuring: identifying meaningful contexts. Proses selanjutnya peneliti memberikan scaffolding kedua untuk menanamkan konsep $(a . b)^{m}=a^{m} b^{m}$. Pada tahap ini peneliti meminta $S_{3}$ untuk mengubah $(2 x)^{5}$ menjadi bentuk perkalian berulang sehingga didapatkan konsep $(2 x)^{5}=2^{5} x^{5}$. Pemberian scaffolding kedua oleh peneliti ini sesuai dengan jenis scaffolding Anghileri level $2 \mathrm{re}$ viewing: students explaining and justifying. Setelah $\mathrm{S}_{3}$ mengetahui kesalahan dalam mengerjakan soal dan memahami aturan dasar $(a . b)^{m}=a^{m} b^{m}$ selanjutnya $\mathrm{S}_{3}$ memperbaiki jawaban soal tes yang ia kerjakan. Proses selanjutnya peneliti memberikan scaffolding ketiga un- tuk menanamkan konsep $\frac{1}{a^{-n}}=a^{n}$. Pada pemberian scaffolding ketiga ini, peneliti memberikan lembar kerja yang berisi beberapa contoh pembagian bilangan berpangkat yang mengarah pada kesimpulan $\frac{1}{a^{n}}=a^{-n}, a \neq 0$. Pemberian scaffolding ketiga yang dilakukan peneliti ini sesuai dengan jenis scaffolding Anghileri level 2 reviewing: students explaining and justifying. Selanjutnya peneliti memberikan pertanyaan arahan sehingga $S_{3}$ menyimpulkan $\frac{1}{a^{-n}}=a^{n}, a \neq 0$. Hal ini sesuai dengan jenis scaffolding Anghileri level 2 yaitu reviewing: prompting and probing question. $\mathrm{S}_{3}$ juga mengalami kesulitan dalam menyederhanakan bentuk $\frac{a^{m}}{a^{n}}, a \neq 0$. Seperti pada pemberian scaffolding kedua (students explaining and justifying), peneliti memberikan scaffolding keempat dengan memberikan beberapa bentuk pembagian eksponen untuk disederhanakan yang akhirnya $S_{3}$ memahami konsep $\frac{a^{m}}{a^{n}}, a \neq 0$. Hal ini sesuai dengan jenis scaffolding Anghileri level 2: reviewing. Selanjutnya $S_{3}$ memperbaiki jawabannya dan tidak mengalami kesulitan dalam menyederhanakan eksponen.

Dalam menyederhanakan eksponen $\mathrm{S}_{4}$ tidak memahami aturan $(a . b)^{m}=$ $a^{m} b^{m}$. Untuk mengatasi kesulitan tersebut, peneliti memberikan scaffolding pertama dengan memberikan lembar kerja yang berisi beberapa contoh bentuk $(a . b)^{m}$ untuk disimpulkan menjadi $(a . b)^{m}=a^{m} \cdot b^{m}$. Hal ini sesuai dengan jenis scaffolding Anghileri level 2 reviewing: students explaining ang justifying. Untuk berikutnya $\mathrm{S}_{4}$ kesulitan dalam menyederhanakan bentuk $\frac{a^{m}}{a^{n}}, a \neq 0$. Peneliti memberikan scaffolding kedua dengan meminta siswa untuk mengubah $\frac{16^{5}}{2^{3}}$ ke dalam perkalian berulang kemudian menyederhanakan hasil perkalian berulang tersebut dengan penyebutnya. Pem- 
berian scaffolding oleh peneliti ini sesuai dengan scaffolding Anghileri level 2 reviewing: parallel modelling. Selanjutnya $\mathrm{S}_{4}$ melanjutkan mengoreksi kembali hasil jawaban pekerjaannya. Setelah mendapatkan scaffolding sebanyak 2 kali $\mathrm{S}_{4}$ sudah memahami bagaimana menyederhanakan eksponen. Namun $\mathrm{S}_{4}$ masih melakukan kesalahan dalam menerapkan aturan $a^{0}=1$. Untuk mengatasi hal tersebut, peneliti memberikan scaffolding ketiga dengan memberikan beberapa soal tentang penyederhanaan bentuk pembagian eksponen dengan bilangan yang sama, sehingga didapatkan konsep $a^{0}=1$. Pemberian scaffolding ketiga oleh peneliti ini sesuai dengan jenis scaffolding Anghileri level 2 reviewing: parallel modelling. Kemudian $\mathrm{S}_{4}$ menyelesaikan kembali jawaban soal dalam menyederhanakan eksponen.

Pemberian Scaffolding oleh peneliti banyak berupa reviewing dan restructuring. Peneliti banyak meminta siswa untuk mengulang kembali dan mengkontruksi ulang pemahaman dan konsep yang dimiliki siswa dengan pertanyaan pertanyaan arahan. Hal ini dilakukan dengan maksud siswa dapat mengembangkan kemampuan yang dimilikinya semaksimal mungkin. Sesuai dengan pendapat Mc Kenzie (1999) yang dikutip oleh Hazir (2010) bahwa "scaffolding delivers efficiency and, if done well, a scaffolded lesson should be efficient. Scaffolding provides the opportunity for students to develop their independence, sense-making and self-confidence, whilst working mathematically"

Pada penyelesaian persamaan eksponen, scaffolding yang diberikan pada keempat subjek dalam menyelesaikan persamaan eksponen juga disesuaikan dengan kesalahan dan kesulitan masing-masing subjek. Berdasar hasil pekerjaan $\mathrm{S}_{1}$ dalam menyelesaikan soal persamaan eksponen, menunjukkan bahwa $S_{1}$ masih belum memahami makna ekspo- nen $2^{(x+1)}$ serta tidak memahami bagaimana cara menyelesaikan persamaan eksponen.

Untuk membantu $\mathrm{S}_{1}$ dalam memahami makna eksponen $2^{(x+1)}$ tersebut, peneliti memberikan scaffolding pertama dengan memberikan perkalian berulang $2^{5}$ kemudian $2^{7}$, kemudian $2^{(x+1)}$. Scaffolding pertama yang dilakukan peneliti ini sesuai dengan scaffolding Anghileri level 2 restucturing: identifying meaningful contexs. Kesulitan $\mathrm{S}_{1}$ selanjutnya adalah menyederhanakan eksponen berbentuk $\frac{a^{m}}{a^{n}}$ dengan eksponen yang memuat variable. Untuk membantu menyelesaikan kesulitan $S_{1}$ peneliti melanjutkan scaffolding kedua dengan memberikan eksponen berbentuk $\frac{a^{m}}{a^{n}}$ tanpa variable kemudian menentukan bagaimana cara menyederhanakannya. Setelah berhasil menyederhanakan eksponen berbentuk $\frac{a^{m}}{a^{n}}$ tanpa variable tersebut, peneliti meminta $S_{1}$ untuk menyederhanakan eksponen berbentuk $\frac{a^{m}}{a^{n}}$ yang memuat variable. Pemberian scaffolding kedua ini sesuai dengan jenis scaffolding Anghileri level 3 developing conceptual thinking.

$\mathrm{S}_{1}$ mengalami kesulitan dalam menyelesaikan persamaan eksponen. $\mathrm{S}_{1}$ tidak memahami bagaimana menyelesaikan persamaan eksponen. Selanjutnya peneliti memberikan scaffolding ketiga dengan memberikan bentuk sederhana persamaan eksponen untuk diselesaikan. Dengan pemberian bentuk sederhana persamaan eksponen untuk diselesaikan, peneliti melakukan scaffolding Anghileri level 2: restructuring: simplifying the problem. Setelah mengerti dan memahami bagaimana menyelesaikan persamaan eksponen, $S_{1}$ mengoreksi kembali jawabannya serta menyelesaikan kembali soal persamaan eksponen tanpa mengalami kesulitan. 
Dari hasil pekerjaan $S_{2}$ dalam menyelesaikan soal persamaan eksponen terlihat $\mathrm{S}_{2}$ melakukan kesalahan dalam menerapkan aturan eksponen $a^{-m}=$ $\frac{1}{a^{m}}, a \neq 0$. Peneliti memberikan scaffolding pertama untuk memahamkan aturan $a^{-m}=\frac{1}{a^{m}}, a \neq 0$ dengan memberikan lembar kerja yang berisi beberapa contoh pembagian bilangan berpangkat yang mengarah pada kesimpulan $a^{-m}=\frac{1}{a^{m}}, a \neq 0$. Karena $\mathrm{S}_{2}$ masih menganggap bahwa $\quad 9^{-3 x+5}=$ $\frac{1}{9^{3 x+5}}$, peneliti selanjutnya memberikan pertanyaan arahan yang membantu $\mathrm{S}_{2}$ memahami bahwa $9^{-3 x+5} \neq \frac{1}{9^{3 x+5}}$ dengan mensubstitusikan suatu nilai $x$ ke persamaan tersebut. Pemberian scaffolding pertama yang dilakukan peneliti ini sesuai dengan jenis scaffolding Anghileri level 2 reviewing: students explaining and justifying dilanjutkan dengan prompting and probing.

$\mathrm{S}_{2}$ dalam menyelesaikan soal tentang persamaan eksponen masih mengalami kesulitan dalam menerapkan aturan eksponen $a^{m} \times a^{n}=a^{m+n}$, selanjutnya peneliti memberikan scaffolding kedua dengan meminta $S_{2}$ untuk menyederhanakan eksponen yang berbentuk $a^{m} \times a^{n}$ dengan menggunakan perkalian berulang seperti yang telah dilakukannya pada soal penyederhanaan eksponen. Hal ini sesuai dengan scaffolding Anghileri level 2 reviewing: looking, touching and verbalising. Selanjutnya $\mathrm{S}_{2}$ mengalami kesulitan dalam menerapkan aturan eksponen $\frac{a^{m}}{a^{n}}, a \neq 0$ yang bilangan pokoknya tidak sama serta memuat variabel. Peneliti memberikan scaffolding ketiga untuk membantu $S_{2}$ dalam menerapkan aturan eksponen $\frac{a^{m}}{a^{n}}, a \neq 0$ tersebut dengan meminta $S_{2}$ untuk mengubah bilangan pokok yang tidak sama ke bentuk eksponen dengan bilangan pokok sama. Setelah bilangan pokoknya sama peneliti meminta $\mathrm{S}_{2}$ untuk menyederhanakan eksponen tersebut. Pemberian scaffolding ketiga yang dilakukan peneliti ini sesuai dengan scaffolding Anghileri level 2 reviewing: students explaining and justifying.

Karena $\mathrm{S}_{2}$ mengalami kesulitan dalam menyelesaikan persamaan eksponen, peneliti memberikan scaffolding keempat dengan memberikan persamaan eksponen yang sederhana untuk diselesaikan. Dengan pemberian bentuk sederhana persamaan eksponen untuk diselesaikan, peneliti melakukan scaffolding Anghileri level 2: restructuring: simplifying the problem. Selanjutnya $S_{2}$ memperbaiki jawabannya serta tidak mengalami kesulitan dalam menyelesaikannya.

Dari hasil tes diagnostic nomor 2 tentang persamaan eksponen $\mathrm{S}_{3}$ melakukan kesalahan dalam melakukan operasi bentuk aljabar serta tidak memahami aturan eksponen $\frac{a^{m}}{a^{n}}, a \neq 0$. Scaffolding pertama yang dilakukan peneliti adalah untuk memahami aturan $\frac{a^{m}}{a^{n}}, a \neq 0$ dengan memberikan pertanyaan arahan (prompting and probing) untuk mengingatkan kembali bagaimana menyederhanakan bentuk $\frac{a^{m}}{a^{n}}$. Selanjutnya untuk membantu mengatasi kesulitan $\mathrm{S}_{3}$ dalam melakukan operasi bentuk aljabar, peneliti melakukan scaffolding kedua dengan memberikan contoh konstekstual dari bentuk aljabar. Hal ini sesuai dengan scaffolding anghileri level 1 environmental provision.

Pada pelaksanaan Scaffolding kedua ini peneliti menyimpulkan bahwa pemberian scaffolding lebih mudah dilakukan jika memberikan bantuan dari konkret kemudian perlahan-lahan menuju abstrak. Sebagai contoh kegiatan scaffolding dengan memberikan contoh konstekstual untuk menyederhanakan bentuk aljabar. Walaupun subjek yang seharusnya sudah pada tahap berfikir abstrak(subjek ber- 
usia sekitar 16 tahun) tetapi faktanya masih perlu disajikan masalah dalam bentuk konkret. Hal ini sesuai dengan pendapat Piaget yang dikutip oleh Bell (1981) yang menyatakan bahwa "new topic in mathematics should be introduced trhough concrete examples".

Setelah $\mathrm{S}_{3}$ memahami bentuk aljabar dari contoh kontekstual, peneliti memberikan dua bentuk aljabar $(2 x-3)-(3 x$ $+5)$ dengan $2 x-3-3 x+5$ untuk memberikan pemahaman bahwa $(2 x-3)-(3 x$ $+5) \neq 2 x-3-3 x+5$. Hal ini sesuai dengan scaffolding Anghileri level 2 reviewing: interpreting students' action and talk. Scaffolding ketiga dan keempat yang dilakukan peneliti selanjutnya adalah untuk mengatasi kesulitan $S_{3}$ dalam menyelesaikan persamaan eksponen. Pada scaffolding ketiga dan keempat yang dilakukan peneliti, peneliti memberikan persamaan eksponen yang sederhana untuk diselesaikan dan dipahami oleh $S_{3}$. Dengan memberikan bentuk persamaan eksponen yang sederhana, peneliti melakukan scaffolding Anghileri level 2 restructuring: simplifying the problem. Selanjutnya $S_{3}$ menyelesaikan kembali jawabannya serta tidak mengalami kesulitan.

Berdasar hasil pekerjaan $\mathrm{S}_{4}$ dalam menyelesaikan soal diagnostic nomor 2 tentang persamaan eksponen, terlihat $\mathrm{S}_{4}$ mengalami kesulitan dalam menyelesaikan operasi bentuk aljabar. Peneliti memberikan scaffolding pertama untuk memahamkan operasi bentuk aljabar dengan memberikan contoh konstekstual bentuk aljabar seperti yang scaffolding yang diberikan kepada $S_{3}$. Selanjutnya peneliti juga memberikan dua bentuk aljabar $(2 x$ $-3)-(3 x+5)$ dengan $2 x-3-3 x+5$ seperti yang diberikan kepada $S_{3}$ untuk memberikan pemahaman bahwa bahwa $(2 x-3)-(3 x+5) \neq 2 x-3-3 x+5$. Hal ini sesuai dengan scaffolding Anghileri level 1 environmental provision dilanjutkan scaffolding Anghileri level $2 \mathrm{re}$ - viewing: interpreting students' action and talk. Scaffolding kedua untuk membantu memahamkan $\mathrm{S}_{4}$ dalam menerapkan aturan eksponen $\frac{a^{m}}{a^{n}}, a \neq 0$ dengan bilangan pokok yang awalnya tidak sama dilakukan peneliti dengan memberikan pertanyaan arahan (prompting and probing) untuk mengingatkan kembali bagaimana menyederhanakan eksponen $\frac{a^{m}}{a^{n}}, a \neq 0$. Sedangkan scaffolding ketiga yang dilakukan peneliti untuk membantu $\mathrm{S}_{4}$ menyelesaikan persamaan eksponen. Karena $\mathrm{S}_{4}$ tidak memahami bagaimana menyelesaikan persamaan eksponen, peneliti memberikan persamaan eksponen yang sederhana untuk diselesaikan. Setelah $\mathrm{S}_{4}$ memahami bagaimana cara menyelesaikan persamaan eksponen dengan bentuk yang sederhana, $\mathrm{S}_{4}$ kemudian mengoreksi dan menyelesaikan kembali jawaban $\mathrm{S}_{4}$ dalam menyelesaikan persamaan eksponen yang diberikan. Pemberian scaffolding ketiga oleh peneliti ini sesuai dengan scaffolding Anghileri level 2 restructuring: simplifying the problem. Setelah $\mathrm{S}_{4}$ memahami bagaimana menyelesaikan persamaan eksponen, $\mathrm{S}_{4}$ selanjutnya menyelesaikan ulang soal persamaan eksponen tanpa mengalami kesulitan.

Dalam memberikan scaffolding kepada empat subjek penelitian, peneliti beberapa kali menggunakan pertanyaan arahan (prompting dan probing) dalam membantu siswa menerapkan dan memahami konsep aturan eksponen. Prompting dan probing telah diterapkan oleh peneliti-peneliti sebelumnya untuk memberikan bantuan kepada siswa. Wood dalam Anghileri (2006) menyampaikan “... with prompting question that successively lead the students toward a predetermined solution”. Begitu pula Kolikant \& Borza (2011) mengatakan "without the tutor's prompts, the students may not have used the story as a tool-to think- with". Pernyataan - pernyataan yang disampaikan 
peneliti tersebut, semakin menguatkan bahwa prompting dan probing dapat digunakan untuk mengatasi kesulitan dan kesalahan siswa dalam menerapkan aturan eksponen.

Berdasar hasil tes akhir yang dilakukan oleh subjek penelitian dapat disimpulkan bahwa kesalahan yang dilakukan siswa dalam menerapkan aturan eksponen mengalamu penurunan setelah diberi scaffolding. Walaupun masih ada beberapa kesalahan yang dilakukan oleh subjek, diantaranya kesalahan dalam mengubah eksponen $\quad\left(3 m^{2} n^{-3}\right)^{2} \quad$ menjadi $3^{2} m^{2} n^{-3.2}$, kesalahan mengubah $3^{-1} \cdot n^{-7} \cdot m^{4}$ menjadi $3 n^{7} \cdot m^{4}$, serta tidak mengubah pangkat negatif menjadi positif pada hasil akhir sesuai pertanyaan, namun kesalahan yang dilakukan subjek tersebut sudah banyak mengalami penurunan. Dari jawaban subjek tersebut, terlihat subjek sudah mulai memahami aturan eksponen dan menerapkannya. Sehingga dapat disimpulkan pemberian scaffolding dengan pendekatan masingmasing individu dengan cara memberikan pertanyaan yang mengarah pada penyelesaian jawaban dapat membantu menurunkan banyaknya kesalahan dalam menerapkan aturan eksponen. Kesimpulan ini sesuai dengan pendapat Bliss (dalam Anghileri, 2006 : 37) yang menyampaikan bahwa scaffolding yang berbentuk urutan pertanyaan dan pernyataan yang mengarahkan pada satu selesaian, kenyataannya lebih membantu (really more like cueing).

\section{SIMPULAN DAN SARAN}

Berdasarkan hasil penelitian dan pembahasan yang telah diuraikan sebelumnya, maka dapat disimpulkan bahwa: Pertama, kesalahan siswa dalam menerapkan aturan eksponen selama penelitian dibedakan menjadi tiga tipe kesalahan, yaitu tipe (1) Basic error, tipe (3) missing information dan tipe (4) partial insight.
Kedua, scaffolding yang diberikan untuk mengatasi kesulitan dan meminimalkan kesalahan yang dilakukan siswa dalam menerapkan aturan eksponen berdasarkan tiga level scaffolding yang dikemukakan Anghileri. Selanjutnya, guru perlu melakukan pembelajaran yang lebih bermakna, sehingga materi yang diajarkan benar-benar dipahami oleh siswa. Bagi peneliti selanjutnya, perlu untuk mengembangkan penelitian tentang keefektifan proses Scaffolding jika diterapkan secara klasikal atau berkelompok.

\section{DAFTAR RUJUKAN}

Anghileri, J. 2006. Scaffolding Practices That Enhance Mathematics Learning. Journal of Mathematics Teacher Education, 9(1), 33-52.

Bell, F.H. 1981. Teaching and Learning Mathematics (in Secondary Schools). Iowa: Wm.C. Brown Company Publisher.

Blanco, L.J., \& Garrote, M. 2007. Difficulties in Learning in Students of the First Year of Pre-University Education in Spain. Eurasia Journal of Mathematics, Science and Technology Education, 3(3), 221-229.

Brodie, K.2010 Teaching Mathematical Reasoning in Secondary School Classrooms. New York. United States of America.

Cowan, P. 2006. Teaching Mathematics. New York: Routledge.

Kolikant, Y.B.D. \& Broza, O. 2011. The effect of using a video clip presenting a contextual story on lowachieving students' mathematical discourse. Educational Studies in Mathematics, 76(1), 23-47.

Legutko, M. 2008. An Analysis of Students' Mathematical Errors in the Teaching-Research Process. Handbook for Mathematics Teaching: Teacher Experiment. A Tool for Re- 
search. Georgia: University of West Georgia, pp. 141-152.

Lim, K.S. 2010. An Error Analysis of Form 2 (Grade 7) Students in Simplifying Algebraic Expressions: A Descriptive Study. Electronic Journal of Research in Educational Psychology, 8(1), 139-162.

Prediger, S. 2011. Why Johnny Can't Apply Multiplication Revisiting The Choise of Operations With Fractions. International Journal of $M a$ thematics Education, 6(2), 65-88.

Savvi, P. S. D. 2014. Analisis Kesalahan dan Perilaku yang Dilakukan Siswa Kelas VII-C MTs. Darul Huda Pasuruan dalam Menyelesaikan Soal Cerita Perbandingan Mata Pelajaran Matematika. Pascasarjana Universitas Negeri Malang: Tesis tidak diterbitkan.

Stuyf, V. 2002. Scaffolding as a Teaching Strategy. Adolescent Learning and Development Journal, 52 (3), 5-18.
Trisulawati. 2009. Analisis Proses Terjadinya Kesalahan Siswa dalam Memecahkan Masalah Berkaitan dengan Garis Singgung Lingkaran. Thesis tidak diterbitkan. Malang: Universitas Negeri Malang.

Ureyen, M., Cetin, N., \& Mahir, N. 2006. The Mistakes Made by the Students Taking a Calculus Course in Solving Inequalities. International Journal for Mathematics Teaching and Learning. (Online), (http://www. cimt.plymouth.ac.uk/journal/ureyen. pdf, diakses 16 Agustus 2016).

Willis, J.M.D. 2010. Teaching To Love Math. Virginia, USA: ASCD

Yakin, M. H. A, 2011. Diagnosis Kesulitan Siswa dalam Menyederhanakan Pecahan Aljabar dan Upaya Mengatasinya dengan Menggunakan Scaffolding. Tesis tidak diterbitkan. Malang: Pascasarjana UM.

Yuli, D. 2015. Analisis kesalahan siswa SMA Kristen Charis Malang dalam Menyelesaikan Soal Cerita Perbandingan Trogonometri Beserta Sacffoldingnya. Tesis tidak diterbitkan. Malang: Pascasarjana UM. 